\title{
VAGUENESS EXPRESSIONS IN ITALIAN, SPANISH AND ENGLISH TASK-ORIENTED DIALOGUES
}

\author{
Miriam Voghera, Carla Borges \\ University of Salerno \\ ABSTRACT \\ In this article, we present a corpus-based analysis on the use of Vagueness Expressions (VEs) in \\ Italian, Spanish and English in Task-oriented Dialogues. Following the distinction among \\ informational, relational and discourse vagueness (Voghera 2012), we compare the width of the \\ functional space of the most frequent VEs. In particular we investigate whether and to what extent \\ the VEs cover all the types of vagueness in the three languages. Quantitative and qualitative analysis \\ brings evidence about a high convergence in the vagueness functions expressed by the VEs of the \\ three languages.
}

KEYWORDS: vagueness, spoken Italian, Spoken English, Spoken Spanish, corpus linguistics.

Speakers can, and actually do, produce signs with different degree of discriminability, according to communicative conditions. We tend to be highly specific and thus to produce very easily detectable signs in controlled and formal situations, both in spoken and written language, while we tend to produce a low degree of specification in informal situations. Using the well-known terminology of Bjorn Lindblom (1990), we can go from hypospeech to hyperspeech, depending on the exigencies of the speaker-addressee pair in the given communicative situation. Whenever a sign falls below the threshold of distinctivity, it becomes vague. Vagueness can affect both the significant and the meaning side of a sign, although it is usually intended as a semantic phenomenon.

Vagueness can depend on systemic factors when we use words, such as bald or tall, whose boundaries are semantically undetermined, but for which we do not have alternative signs. In other circumstances, vagueness is intentional - i.e. a speaker's choice - when a) there is a lack of information; b) speakers show difficulty or reluctance to establish a clear relation with the utterance or the addressee; or c) have difficulty due to online programming and production (Caffi 2007, Kaltenböck et al. 2010, Bazzanella 2011, Overstreet 2011, Jucker et al. 2003, Voghera 2012, Ghezzi 2013). These three main causes of vagueness determine different types of vagueness, according to the prevalent domain they are related to: a) information; (interpersonal) relations and 3) discourse. Informational vagueness 
affects the propositional content of an utterance, but can result also from uncertainty in linguistic uses and thus produce metalinguistic vagueness. Relational vagueness has a social function, since it affects the pragmatic dimension of communication and the force of the illocutionary act. Discourse vagueness can manifest itself in spoken communication through disfluences and usually produces a low degree of content density; it can occur also when we do not write in ideal conditions, such as when we take notes, or in written texts recorded by non-competent speakers, such as young children, L2 learners or languageimpaired patients ${ }^{1}$.

(1) Informational vagueness

S1: ya sitting down on a park bench looking at what's a sort of portable television (SD)

(2) Relational Vagueness

S2: eh oh about an inch up from the monu-- just just curve sort of curve round a circle, sort of (MP)

(3) Discourse Vagueness

S1: ma-- make mark a cross above the caravans, go round, like, just like an oval, like half an oval until you come to sort of top of the old mill like say the corner of the roof (MP)

Informational vagueness, relational vagueness and discourse vagueness can be conveyed through many different types of constructions, i.e. combination of form and meaning pairs (Goldberg 1995), which we name conventionally Vagueness Expressions (VEs). Table 1 offers a list of the most common types of VEs, based on Channel (1994), in the three languages we consider in this article: English, Italian and Spanish.

\begin{tabular}{|c|c|c|c|}
\hline $\begin{array}{l}\text { Vagueness } \\
\text { Expressions }\end{array}$ & Italian & Spanish & English \\
\hline $\begin{array}{l}\text { Inherently vague } \\
\text { nouns: } \\
\text { "placeholders", } \\
\text { "dummy nous" }\end{array}$ & $\begin{array}{l}\text { cosa, roba, discorso, } \\
\text { fatto, faccenda, } \\
\text { affare, ... }\end{array}$ & $\begin{array}{ll}\text { cosa; } & \text { cuestión; } \\
\text { problema, ... } & \end{array}$ & $\begin{array}{l}\text { thing(s), stuff, thingy, } \\
\text { thingummy, ... }\end{array}$ \\
\hline $\begin{array}{l}\text { Vague additives } \\
\text { approximators }\end{array}$ & $\begin{array}{l}\text { verso, circa, tipo, una } \\
\text { specie di... }\end{array}$ & $\begin{array}{l}\text { como; una especie de; } \\
\text { tipo ... }\end{array}$ & $\begin{array}{l}\text { around seven, sevenish, } \\
\text { almost a dozen, ... }\end{array}$ \\
\hline General extenders & $\begin{array}{l}\text { eccetera, e così via, e } \\
\text { cose del genere, ... }\end{array}$ & $\begin{array}{l}\text { cosas por el estilo; cosas } \\
\text { así; cosas como esas; y } \\
\text { tal... }\end{array}$ & $\begin{array}{l}\text { and everything, and stuff, } \\
\text { or something, ... }\end{array}$ \\
\hline $\begin{array}{l}\text { Vague quantifiers } \\
\text { vague amounts and } \\
\text { numbers }\end{array}$ & $\begin{array}{l}\text { per un pelo, un sacco, } \\
\text { un mucchio, un } \\
\text { casino, un paio, un } \\
\text { tocco, un'ombra, due } \\
\text { o tre ... }\end{array}$ & $\begin{array}{l}\text { un montón de; montones } \\
\text { de; un par }\end{array}$ & $\begin{array}{l}\text { heaps of, loads of, } \\
\text { oodles of, a touch of, a } \\
\text { bit of, some, many, most, } \\
\text { umpteen... }\end{array}$ \\
\hline $\begin{array}{l}\text { Frequency } \\
\text { expressions }\end{array}$ & $\begin{array}{l}\text { a volte, } \\
\text { probabilmente, } \\
\text { forse... }\end{array}$ & $\begin{array}{l}\text { a veces; quizás; tal vez; } \\
\text { probablemente... }\end{array}$ & $\begin{array}{l}\text { sometimes, usually, now } \\
\text { and again, likely, ... }\end{array}$ \\
\hline
\end{tabular}

\footnotetext{
${ }^{1}$ The spoken examples are reported in exemplified transcription; S1 and S2 indicate respectively the numbers of speakers; SD and MT indicate Spot the difference dialogue and Map Task dialogue respectively. 


\begin{tabular}{|c|c|c|c|}
\hline Round numbers & $\begin{array}{l}\text { guadagna } 50.000 \\
\text { euro all'anno... }\end{array}$ & $\begin{array}{l}\text { gana } 50.000 \text { euros al } \\
\text { año... }\end{array}$ & $\begin{array}{l}\text { she makes } \$ 50,000 \text { a } \\
\text { year... }\end{array}$ \\
\hline $\begin{array}{l}\text { Hyperbolic } \\
\text { expressions }\end{array}$ & $\begin{array}{l}\text { oggi ho un milione di } \\
\text { cose da fare, è mille } \\
\text { volte meglio... }\end{array}$ & $\begin{array}{l}\text { un millón de cosas que } \\
\text { hacer; es mil veces mejor } \\
\text {... }\end{array}$ & $\begin{array}{l}\text { I have a million things to } \\
\text { do, it's a hundred times } \\
\text { better... }\end{array}$ \\
\hline Intonation & toni non discendenti & tono creciente & rising pitch \\
\hline Irrealis & $\begin{array}{l}\text { modi, frasi ipotetiche, } \\
\text {.. }\end{array}$ & $\begin{array}{ll}\text { modos, } & \text { orationes } \\
\text { ipoteticas } & \end{array}$ & mode, if clauses... \\
\hline Indefinite & $\begin{array}{l}\text { un tipo, uno, } \\
\text { impersonali, plurali.. }\end{array}$ & $\begin{array}{ll}\text { pronombres } & \text { indefinidos; } \\
\text { adjetivos } & \text { indefinidos; } \\
\text { plurales } & \end{array}$ & $\begin{array}{l}\text { pronouns, } \\
\text { plurals... }\end{array}$ \\
\hline
\end{tabular}

Table 1: Vagueness expressions in English, Italian and Spanish

In recent years, a number of studies have noticed that there is a great similarity in the way languages express intentional vagueness (Cutting 2007; Ghezzi 2013; Mihatsch 2007, 2016; Voghera\&Collu in press). This encourages interlinguistic studies, though it is not easy to compare VEs crosslinguistically because of their multiple functions. Many variables are at stake in the use of VEs in spontaneous communication and, although in an utterance we can individuate the primary target of vagueness, all domains are always potentially involved. The three types of intentional vagueness not only can combine and overlap in several contexts, but can also be strategically associated (Caffi 2007; Voghera and Collu in press). Vagueness at informational level can be used to mask relational vagueness and, in turn, discourse vagueness can be caused by informational vagueness.

\footnotetext{
(4) danno più importanza alla religione no? come_ manifestazione tipo_ eh insomma delle feste così 'they put more relevance on religion don't they? like an event like ehm well of celebrations and stuff like that'
}

In (4) the speaker, on the one hand, expresses vagueness in the propositional content because she is uncertain about how to define the attitude towards the religion she is talking of, but, on the other hand, the use of a rhetorical question expresses relational vagueness, i.e. attenuate the force of her assertion. Finally, the tentative formulation manifests discourse vagueness through the repetition of several discourse markers: tipo, insomma, cosi.

In other words, the three levels of vagueness interact and it is not easy to discern the contribution of every single VE, rendering difficult the interlinguistic comparison of excerpts of spoken dialogues. For these reasons, we propose an analysis based on dialogues elicited in the same communicative contexts. They are task-based dialogues in which speakers work together to achieve a task: draw a map, individuate the differences in two pictures and so on. These kinds of dialogue present the advantage of showing the use of VEs in the same communicative conditions, allowing a better comparison of the constructions in different languages.

\section{OUR RESEARCH AND METHODOLOGY}

Our research aims to compare the form and the width of VEs' functional space; in particular we investigate 1) whether and to what extent they cover the three types of intentional vagueness and 2) whether there is a relation between the type of constructions and the vagueness they convey. Ultimately, this will allow us to delineate a map of differences and correspondences of the usage of these VEs in the three languages. 
The VEs we choose are some of the most frequent in the three languages and therefore most studied. We can distinguish three basic groups of VEs. A first group is constituted by VEs, which derive from taxonomic nouns. Over the last few decades, a number of studies have been dedicated to non-nominal constructions of taxonomic nouns in several languages. They cover a wide area, which express all the three types of intentional vagueness, although the functional boundaries of each construction differ from language to language. In our dialogues we found the construction [[a TN of] X], in which the Taxonomic Noun position can be lexically occupied by Italian specie (lit.' kind'), Spanish especie (lit. 'kind') and English sort and kind. As we will see in paragraph 3.2, in English we found the construction without the determiner [sort/kind of], which expresses a quite different type of vagueness. The Italian costruction [tipo N] (lit. 'type'), which also originates from a taxonomic noun, belongs rather to the second group of VEs, because as like and como (lit. 'like'), it operates as comparative marker. In many languages, the comparative markers can be used as VEs, deploying the semantic and cognitive process of an analogy (Mihatsch 2009; Voghera 2013, 2014). By this way, the speakers categorise new items and/or situations through elements, which are familiar in other object or situations. These VEs are conveniently used in our dialogues, in which the speakers must describe objects that their addressees cannot see and therefore they approximate the unknown to the known one. The last group include two VEs: Italian diciamo and Spanish digamos ('Let'say'). They are two discourse markers, whose function is to emphasize the interactive structure of the conversation. In fact, earlier studies indicate that both diciamo and digamos are mainly related to intersubjective functions, such as mitigation. According to Briz, Pons e Portolés (2008) digamos is also used to convey approximation and metalinguistic approximation.

Our analysis aims to offer both quantitative and qualitative data on the kind of vagueness expressed in the eleven dialogues, whose features are summarized in Table 3.

\begin{tabular}{|c|c|c|c|c|c|c|}
\hline Corpora & Language & $\begin{array}{c}\text { No. of } \\
\text { Speakers }\end{array}$ & Sex & Age & Task & $\begin{array}{l}\text { Recording } \\
\text { Period of }\end{array}$ \\
\hline \multirow[t]{5}{*}{ PraTid } & \multirow[t]{2}{*}{ Italian } & \multirow[t]{2}{*}{8} & 4 males & \multirow{2}{*}{$\begin{array}{l}\text { University } \\
\text { students }\end{array}$} & \multirow{2}{*}{$\begin{array}{l}\text { Spot the } \\
\text { difference }\end{array}$} & \multirow[t]{2}{*}{$2000-2010$} \\
\hline & & & 4 females & & & \\
\hline & \multirow{2}{*}{$\begin{array}{l}\text { Peninsular } \\
\text { Spanish }\end{array}$} & \multirow[t]{2}{*}{8} & 2 males & \multirow{2}{*}{$\begin{array}{l}\text { University } \\
\text { students }\end{array}$} & \multirow{2}{*}{$\begin{array}{l}\text { Spot the } \\
\text { difference }\end{array}$} & \multirow[t]{2}{*}{$2000-2010$} \\
\hline & & & 6 female & & & \\
\hline & English & 4 & 4 males & Academics & $\begin{array}{l}\text { Spot the } \\
\text { difference }\end{array}$ & $2000-2010$ \\
\hline \multirow[t]{2}{*}{$\mathrm{HCRC}$} & \multirow[t]{2}{*}{ English } & \multirow[t]{2}{*}{6} & 1 male/ & \multirow{2}{*}{$\begin{array}{l}\text { University } \\
\text { students }\end{array}$} & \multirow[t]{2}{*}{ Map Task } & \multirow[t]{2}{*}{ Early 90s; } \\
\hline & & & 1 female & & & \\
\hline
\end{tabular}

Table 2: dialogue features

In the task-oriented dialogues the speakers communicate separated by a table and cannot see each other, therefore they must rely only on what they say. PraTid Corpus ${ }^{2}$ collects the dialogues of couples of speakers who try to "spot-the-difference" in two different drawings. Figure 1 provides an example of the drawings used for the task.

\footnotetext{
${ }^{2}$ For the entire project bibliography see: http://www. parlaritaliano.it/index.php/it/component/content/article/34-pratid-nellelingue-europee (Savy 2010). 

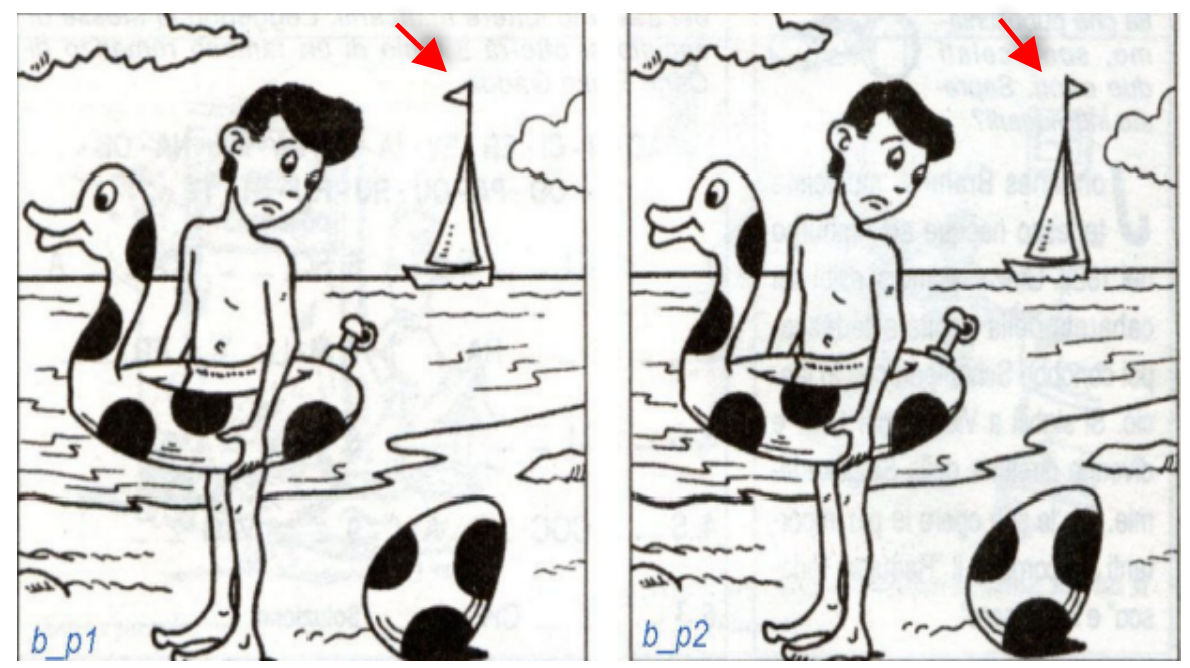

Figure 1 (http://clips.unina.it)

In HCRC Map Task Corpus ${ }^{3}$ the speakers of the dialogues receive two maps, but they do not know that they are different. One of the speaker has a route on the map and must give instructions to the other to make him reproduce the route. Figure 2 provides an example of the maps used for the task.

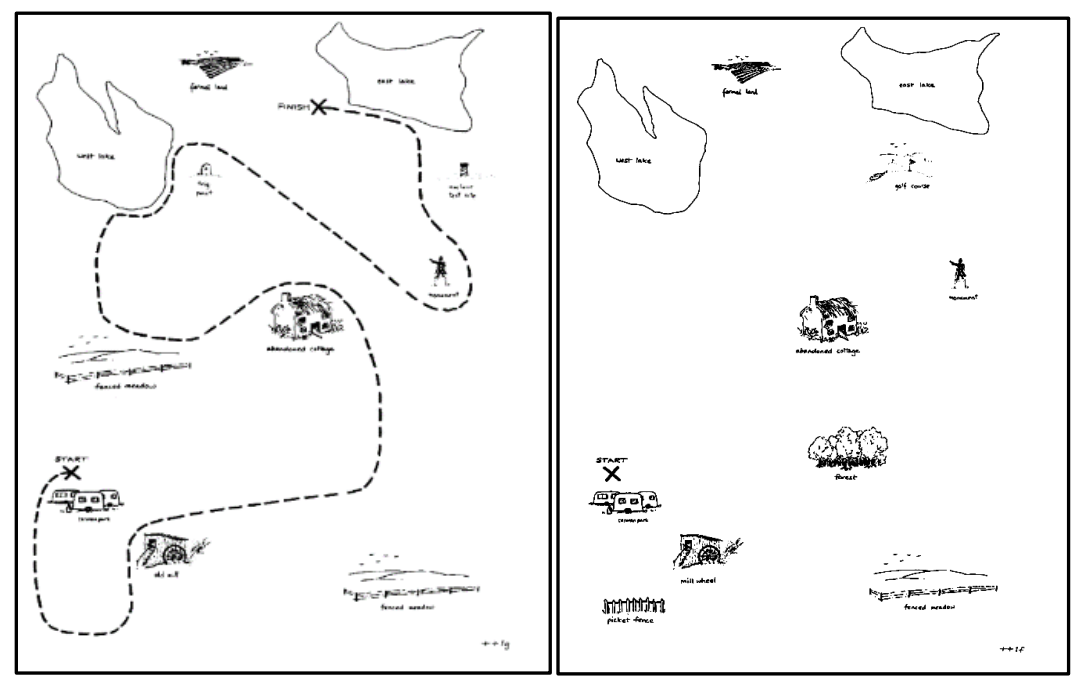

Figure 2: two examples of maps with and without the draw of road (http://groups.inf.ed.ac.uk/maptask/)

\section{THE VAGUENESS EXPRESSIONS: THE DATA}

We systematically conducted a threefold analysis, taking into consideration: a) the context in which the VE occurs, including the sequence of preceding or following turns, when necessary; b) the possible phonetic cues of vagueness, such as intonation profile, 
pauses, hesitations, interjections, vowel lengthening; c) the syntactic construction the VE is part of. In total, we analysed 242 VEs so distributed:

\begin{tabular}{|c|c|c|}
\hline Languages & VEs & Number \\
\hline \multirow[t]{4}{*}{ Italian } & Una specie di & 4 \\
\hline & Tipo & 11 \\
\hline & Diciamo & 65 \\
\hline & Total & 80 \\
\hline \multirow[t]{4}{*}{ Spanish } & Una especie de & 7 \\
\hline & Como & 53 \\
\hline & Digamos & 21 \\
\hline & Total & 81 \\
\hline \multirow[t]{4}{*}{ English } & Like & 32 \\
\hline & (A) sort of & 30 \\
\hline & (A) kind of & 19 \\
\hline & Total & 79 \\
\hline
\end{tabular}

Table 3: Number of VEs analysed

\subsection{Una specie di and una especie de}

In the analysed dialogues, speakers use una specie di and una especie de to convey vagueness in the propositional content (Mihascht 2010). In all cases, una specie diand una especie de are used as noun modifiers with the function of approximators (Voghera 2017a).

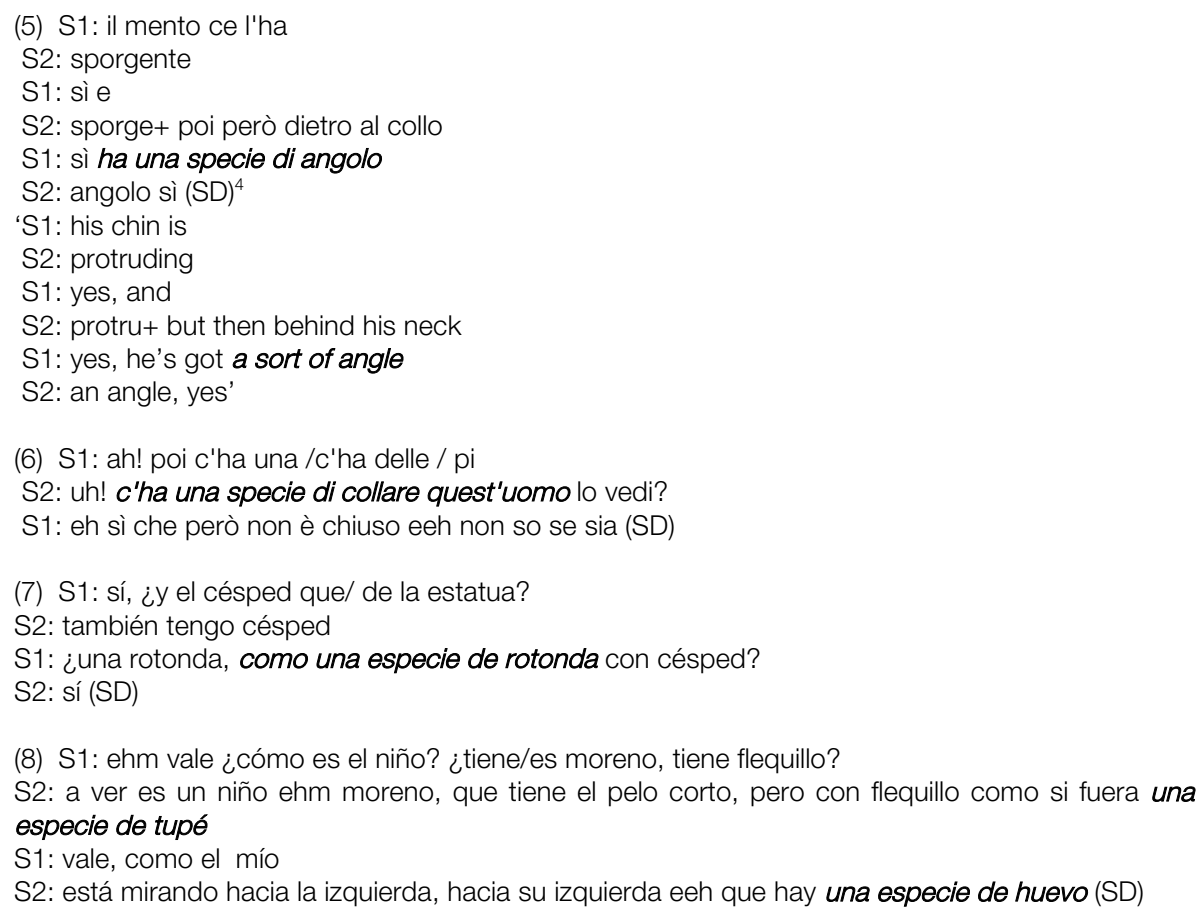

In all the examples una specie di and una especie de are noun modifiers, which play the role of conveying a tentative description of the drawing:

${ }^{4}$ Here are the meaning of transcription conventions: + truncated word; / false start with no interruption. 
(9) ha [[una specie di $]_{\text {Approx }}$ angolon]NP $\rightarrow$ ha più o meno un angolo

he's got [[a sort of ] Approx $_{\text {angleN] }} \rightarrow$ he's got more or less an angle

10) como [[una especie de $]_{A p p r o x}$ rotondaN $]_{N P} \rightarrow$ como más o menos una rotonda

\section{2 (A) sort of and (a) kind of}

Many works on a sort of and a kind of have shown that their function goes beyond that one of noun modifiers (Denison 2002; Jucker Smith and Lüdge 2003; De Smedt et al., 2007) and also in our dialogues we detect vary functions. Both VEs can occur with and without the determiner a and followed by like: sort of like, kind of like. Generally speaking, in our dialogues, while we found a pretty clear distinction among the sort-constructions, the situation appears more confuse as far as the kind-constructions are concerned.

Among the sort-constructions, the one with the determiner functions mainly as una specie diand una especie de, i.e. it approximates the meaning of the linguistic item that it modifies:

(11) S1: ya sitting down on a park bench looking at what's [[a sort of Aprox $_{\text {portable television } \mathrm{N}] \mathrm{SN}}$ (SD)

(12) S1: you're going in [[ a sort of Approx $\left._{\text {curveN }}\right]_{\mathrm{SN}}$ to the bottom of the map then round the old mill (MT)

The determiner construction conveys informational vagueness and can occur also with other type of determiners or quantifiers, such as some or that:

(13) S1: has he got some sort of tattoo? (SD)

(14) S1: see that sort of straight angle

S2: $\mathrm{mmhmm}$

S1: do a straight line going to your towards your your right down to the left-hand side you're going down (MT)

Informational vagueness is, in fact, basically expressed by the construction with the determiners. We found only one occurrence in which the determiner construction expresses discourse vagueness:

(15) S1: see the curve in the at the bottom of the west lake? that sort of, can you see a round curve (MT)

Differently from the construction with the determiner, sort of is mainly use to expressed as in in (16):

(16) S1: no, quite just sort a wee gradual one..

$[\ldots]$

S1: and you sort of make a circle round up towards the west lake you go up to the west lake and then

$[\ldots]$

S1: but you're supposed to curve underneath there to about halfway you're meant to like sort of draw a line following that line to about halfway and then go down round past the monument past your golf course I think as well (MT)

In $26.6 \%$ of cases the speakers use sort of to convey that they are not convinced about their lexical choice and at the same time would like to limit the semantic-pragmatic scope of what they are saying. In fact, in examples (17) and (18) sort of functions both as a metalinguistic approximator and as a hedge.

(17) S1: do a curve right up to your right

S2: right okay

S2: right

S2: I'll draw that 
S1: sort of $d$-- gradual curve to your right (MT)

(18) S2: so would, you know, head sort of for the west lake now avoiding you know (MT)

A more complicated case is the following one, in which the construction without the determiner, which can be considered as an approximator, according to native judgements:

(19) S1: ma-- make mark a cross above the caravans, go round like/just like an oval like half and until you come to sort of top of the old mill like say the corner of the roof (MT)

Here in the construction without determiners the speaker wants to express that she is uncertain about how to communicate and formulate the discourse. In fact, she proceeds with more than one formulation, as in (19): sort of top of the old mill like say the corner of the roof.

A clear hedging function can be identified when sort of is in the far-right periphery of the utterance. In these cases, only about 3\% of total, the construction aims to alert the addressee that he must be flexible in interpreting what the speaker is saying, i.e. sort of has an intersubjective meaning (Traugott 2010). The example (20) is very interesting because presents two occurrences of sort of the first one conveys uncertainty about the lexical choice and the second one stresses that what it has been said must not be intended literally.

(20) S1: eh oh about an inch up from the monu-- just just curve sort of curve round a circle, sort of (MT)

We must signal a unique occurrence of sort of thing as general extender and therefore conveying informational vagueness.

(21) S2: but I mean that that's like this is the third attempt, sort of thing (MT)

Sort of like is always used to express discourse vagueness. For example, in (22) sort of like is followed by a long pause. This may signal that the speaker is having speech hesitations, or that he is having difficulties in finding the most appropriate word.

(22) S1: can you make sort of like right if you make a sort of (MT)

The kind-constructions in our dialogues are mainly used to express discourse vagueness. In most cases, a kind of, and kind of like occur in utterances, in which the speakers show difficulties in planning and formulating the speech, as in (23), (24) and (25). All these examples are characterised by pauses, hesitations and interjections and in all cases these VEs do not add any semantic content to the utterance.

(23) S2: it's kind of like a yeah ehm three? (MT)

(24) S2: yeah I mean describing them could be a bit tricky there's a kind of like/ the bottom one there's the/looks like (MT)

(25) S2: his right eye+ the eye th+ you know, on on the/on the hi+ /his left eye, the eye on our right is a kind of//right on the edge of his face (MT)

As we can see, in these utterances we have more than one VE, as often happens in cases of discourse vagueness. As we already noted in Voghera \& Collu (in press), Informational Vagueness is normally expressed by single VEs, while we often find clusters of VEs to convey the other two types of vagueness. In this case, VEs behave like other textual or pragmatic devices, which do not affect the propositional plan, such as discourse markers, which often form a sort of chain construction. 
The construction with the determiner can be used to approximate the propositional content, as in (26), but we find examples without the determiner, when the modified item is not a noun and then kind of is not part of a Noun Phrase (27):

(26) S2: I mean it's/I thought/ a kind of deflated or malformed beach ball (MT)

(27) S1: how are they? ehm he looks [kind of funny] $]_{\text {Adj }}$ act+ no you say, no you mean/ come to mention it (SD)

Also kind of like can convey informational vagueness:

(28) S2: well it's down to a kind of like the line of his chin (SD)

A kind of can be used with or without determiners also to express a metalinguistic approximation. As we can see in (29), the speaker is describing the waves of the sea shown in the picture, which have the shape of an S. In this case a kind of like is used to alert his interlocutor that the term must not be understood literally.

(29) S2: what about the ripples to the right of the stopper on his rubber ring? I've got a kind of like three -esses- they (SD)

An analogue situation is reported in (28), in which the speaker is trying to describe a shape impressed in the sand, similar to a bird.

(30) S2: [...] and then above that joinin' the edge of the picture there's another kind of like bird

shape, you know, a drawn bird shape with a longer left wing than a right wing (SD)

A good paraphrase of what the speaker is trying to say could be: "I am aware that the word bird is not the most appropriate one, but it is the only one that comes to my mind." In other words, the speaker uses kind of as metalinguistic approximator because the shape that must be described has not a proper name. These cases are fairly frequent in map task dialogues and in fact represent $37 \%$ of total occurrences.

Sometimes, kind of and a kind of are used to alert the interlocutor that the term used must not be understood literally. However these examples represent the minority of cases:

(31) S1: if if ducks can smile yeah it looks kind of happy so god knows what is happening (SD)

(32) S2: mh possibly than and underneath that there are a kind of threesome sea-gull shaped lines (SD)

Finally in one third of cases speakers, use kind of to hedge an assertion. In this case kind of is not in clause final position, but modifies the predicate of the utterance, which expresses the illocutive force of the utterance.

(33) S2: Looks like a space you call a cone it's kind of got four bits (SD)

\subsection{Tipo}

In our dialogues we found only the costruction [X è tipo $Y]$ (' $X$ is type $Y$ '), in which the original taxonomic noun introduces a second member of a comparison to establish not an equivalence, but an analogy (2014). As como and like, tipo works as a similative marker (Haspelmath-Buchholz 1998) and it is well distinguished from the equative Italian marker come.

(34) Ti sei vestito come lui

'You are dressed like him'

(35) Ti sei vestito tipo lui

'You are dressed kind of like him' 
The sentence in (34) means that the two persons wear the same clothes, while the one in (35) expresses just that the clothes are more of less of a similar type These uses are very common today in Italian, but in the period in which our data were collected they were probably still limited to informal speech. This explains the few occurrences in our dialogues, which took place in an academic context.

In $91 \%$ of contexts tipo expresses informational vagueness. In half of the cases it appears in comparisons, in which indicates that there is a relationship of similarity between the two objects described:

(36) S1: il mento è<ee> tipo il naso sembra una scarpa (SD)

'S1: his chin it's like his nose'

In the other half of context, tipo keeps the role of similative marker, but it does not occur in copular sentences and therefore comparison constructions:

(37) S2: bravo esattamente come il mio, fa tipo un cerchio eeh un cerchio/un semicerchio perché solo una parte ne vediamo (SD)

'S2: yes, exactly like mine, it's kind of like a circle hmm/ a semicircle because we can see only a part'

Finally, as already noted in Voghera( 2013,2014$)$, tipo can function as focuser. In $8.3 \%$ of cases, the speaker uses tipo to highlight the focal point of the utterance, as we see in (38).

(38) S2: e ahah sì sì okay ci sono sì sì sì sc+ e ee ehm e il mento è tipo parallelo al al naso sì perché se mi hai detto che c'è la linea deve essere perfettamente uguale al disegno (SD)

In this example the use of tipo does not add any semantic content to the utterance. In fact, the man's chin is perfectly parallel to his nose, thus there is no approximation. Thus, on the contrary, by using tipo here the speaker wants to highlight the element followed by tipo, i.e. parallelo (parallel) and say that the nose and the chin are perfectly parallel. In this example tipo can be paraphrased as really or exactly and thus has a function which is opposite to that of approximating.

\subsection{Como}

In the dialogues como expresses informational vagueness in $75.4 \%$ of cases. In the following example, we can see that the speaker uses como to approximate the semantic content (Mihatsch 2009). In same way as tipo, como create a similative comparison, which can be explicit or implicit, as in (39) and (40):

(39) a.S1: ahah sí mhmh vale ehm bueno, en la mía/en mi dibujo el hombre también tiene como un teléfono con una pantalla en la y en la pantalla aparece un perro (SD)

b. el hombre también tiene como un teléfono < tiene algo como un teléfono

(40) a. S2: mhmh sí eeh ¿alrededor de la estatua hay como un césped? (SD)

'S2: hmm yeah, around the statue is there like a lawn?'

b. hay como un césped? < hay algo como un césped?

'is there like a lawn? < is there something like a lawn?'

As well as a sort of and kind of, also como is used as a metalinguistic approximator to signal the use of unusual terms. In (41) we have quite the same utterance we saw in English in (18), in fact we can even notice that both Spanish speaker and English speaker are approximating the same referent.

(18) S2: what about the ripples to the right of the stopper on his rubber ring? I've got a kind of like

three-esses- they (SD) 
(41) S2: y luego abajo hay como tres que son como eses y la del medio es más pequeña (SD)

(42) S2: ¿sí? ¿el hocico es grande\#?

S1: $\mathrm{mhmh}$

S2: ¿es negro y como con una media luna blanca? (SD)

In $15.1 \%$ of cases como is used as a hesitation marker. This is clear in (43) where the speaker changes his project: in fact in this example the speaker's speech is interrupted, and indicates that he/she is having difficulties in formulating his/her speech.

(43) S2:¿sabes cómo te quiero decir? así como<oo> un (SD)

Finally, in $9.4 \%$ of cases como expresses relational vagueness, i.e. it is used to hedge the illocutionary force of the utterance. In these cases, the speaker communicates that her utterance must not be interpreted as a statement, but as an expression of uncertainty in the description the expression of a personal tentative to report or describe. In these cases, as in (44) and (45) como could be replaced by pienso.

(44) S1: no, el de la/el de arriba del todo es como más finito y pero más o menos sí de la misma distancia y el otro empieza con un arco más grande (SD)

(45) S2: pero arriba hay como una parte que es blanca (SD)

\subsection{Like}

As already said, like, as como and tipo, developed the function of marking similative comparisons, as in (46). Here the speakers are describing the area under a statue and the they do not agree about what they see on their maps: a flower bed or grass? Since it is not clear which of the two is the right description, the second speaker presents the information in a vague way using like ${ }^{5}$.

(46) S2: ok and then there's like like ehm a flower bed going around the plant yeah? (SD)

S1: ya! ok well it looks like grass not not flowers

S2: yeah yeah the same here

These uses of like constitute only $21.8 \%$ of cases, while in most of the contexts, $71.8 \%$, like is used as focuser, confirming data from previous studies (Miller\&Weinert 1995). As we can see in the following examples, speakers use like to call the attention of the addressee on what they are saying. In all these cases the omission of like would not alter the propositional content, but the dynamic between backward and forward informative elements.

(47) S1: uh-huh, no, you don't actually go under the old mill you go like round it. Like, see the side where the steps are? (MT)

(48) S1: So you must, like, have to trace round it (MT)

Finally, in $6.25 \%$ of cases like is used as a hesitation marker. In (49), the speech is interrupted and there are numerous pauses before and after the occurrences of like.

(49) S1: ma-- make mark a cross above the caravans, go round, like, just like an oval, like half an oval until you come to sort of top of the old mill like say the corner of the roof. (MT)

\subsection{Diciamo and digamos}

Diciamo can express all the three types of vagueness (Holker 2005). It expresses informational vagueness in $23 \%$ of cases, mostly as a metalinguistic approximator. If we

${ }^{5}$ For a complete discussion on Like functions see Meehan, 1991; Miller e Weinert 1995; Jucker e Smith, 1998; Müller, 2005 Normas (ISSN: 2174-7245) | 
consider the following extract, we can notice that diciamo is used to mark a figurative use of the expression mezzaluna 'half-moon'.

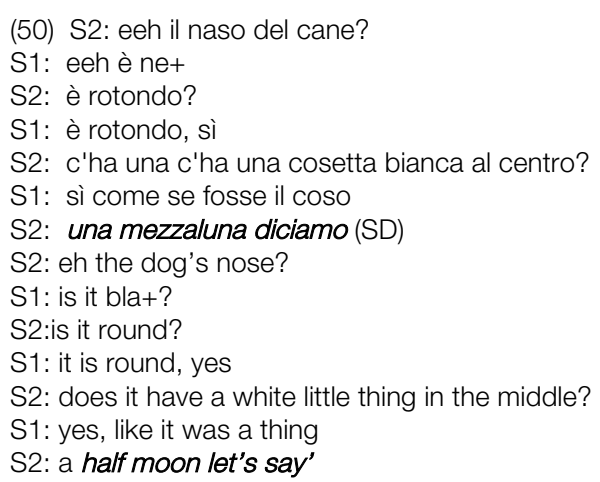

In $15.3 \%$ of contexts diciamo expresses relational vagueness and in half of them it functions as a metacommunicative marker to signaling to the interlocutor that the speaker is making hypotheses about what is being described. For example, in (51) S1 presents the information as if he were thinking aloud. His hypotheses are later confirmed by S2.

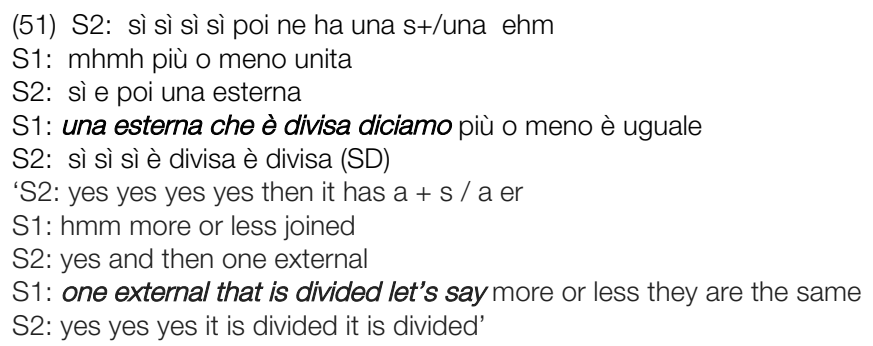

In the other half, diciamo introduces the speaker's point of view. This function is performed by diciamo cosi and is used to highlight the speaker's hypotheses and his/her choice of words. In fact, in (52) diciamo cosi expresses not only the speaker's hypotheses, but also uncertainty about the term visiera visor'. It would seem that the function of diciamo is to express a conjecture while the adverb cosi focuses on the chosen term.

(52) S2: ehm e il cappello del del cavaliere

S1: sì è tipo quello là di Mario Bros

S2: mh me lo puoi raccontare un po' meglio?

$\mathrm{S} 1$ : cioè diciamo così 'na visiera (SD)

S2: hmm and the knight's hat?

S2: yes it's kind of like the one that has Mario Bros

S2: hmm could you describe it better?

$\mathrm{S} 1$ : I mean, let's say that it has a visor'

Finally, in the great majority of cases, diciamo operates at the discourse level. As stated above, in this case VEs do not alter the propositional content and do not result in an attenuation of the illocutionary force, instead they dilute the content of the utterance. For example, in (53) the speaker uses diciamo as a filler. This is even clearer if we listen to the conversation because it can be noticed that this speaker overuses this VE.

(53) S2: ecco c'è la prima onda

S1: s̀

S2: diciamo la onda tutta, non le conto quelle piccoline

S2: ecco adesso ti parl+/la terza/ diciamo parte proprio (SD)

\footnotetext{
${ }^{6}$ Some of the main studies related to diciamo and digamos see: Bazzanella 1995; Waltereit 2006 and Briz, Pons e Portolés (2008). 
'S2: so there's the first wave

S1: yeah

S2: let's say the whole wave, not the small ones

S1: ok, so now l' $m$ going to say something abo+/the third one/ let's say it starts just'

In (54), instead diciamo functions as a hesitation marker, in fact the utterance is incomplete and presents numerous hesitations.

(54) S2: eh e diciamo è un ehm (SD)

'S2: hmm and let's sayit's an hmm'

Digamos, as well as diciamo, operates on the three levels of vagueness. In $19 \%$ of contexts, digamos is used as a metalinguistic approximator. In (55) the speaker is describing a picture in which there is a man with only four fingers. Here the speaker uses digamos because he is not sure that pulgar (thumb) is the correct word to indicate the man's finger.

(55) S1: iqué más! ¿Cuántos dedos tie+? ¿< Cuántos dedos tiene?

S2: ah ah eso cuatro dedos

S1: ¡cuatro! vale, sí

S2: $\mathrm{mh}$ uno lo tiene como si estuviera pulsando una de las teclas

S1: o sea el el pulg+ el pulgar, digamos (SD)

In most cases, $76.1 \%$, digamos expresses discourse vagueness. In half of the contexts as a filler (56), in the other half as a marker of hesitation (57).

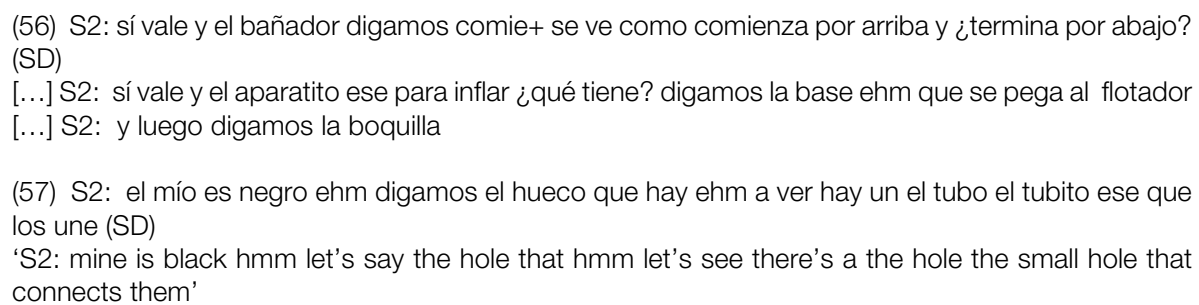

Finally, in $4.7 \%$ of cases the speaker uses digamos to hedge the utterance.

(58) S1: sí sí, sí llega casi hasta el el borde del dibujo digamos (SD)

S1: yeah yeah, yeah it almost comes up to the edge of the drawing let's say

\section{CONCLUSIONS}

The picture we obtained from the analysis is complex, but allows some general reflections that can be better explained comparing the two following figures in which we summarise the quantitative and qualitative data. In the first one, we grouped the meanings and the functions that more frequently are used to express each types of vagueness in the dialogues. The picture shows the ramification of functions and meanings that can be assigned to different types of vagueness. The identification is not always easy because, as we see from the following Table 4, most of the VEs can express different types of vagueness through different functions, which are in many cases strongly intertwined. The table reports them in a decreasing order and quantitative data suggest that most of VEs, in fact, have a prevalent function.

\begin{tabular}{c|clr} 
VEs & \multicolumn{1}{c}{$\begin{array}{c}\text { Type of } \\
\text { Vagueness }\end{array}$} & Function & Frequen \\
& cy \\
\hline una specie di & Informationa & Approximatio & $100 \%$ \\
& I vagueness & $\mathrm{n}$ &
\end{tabular}




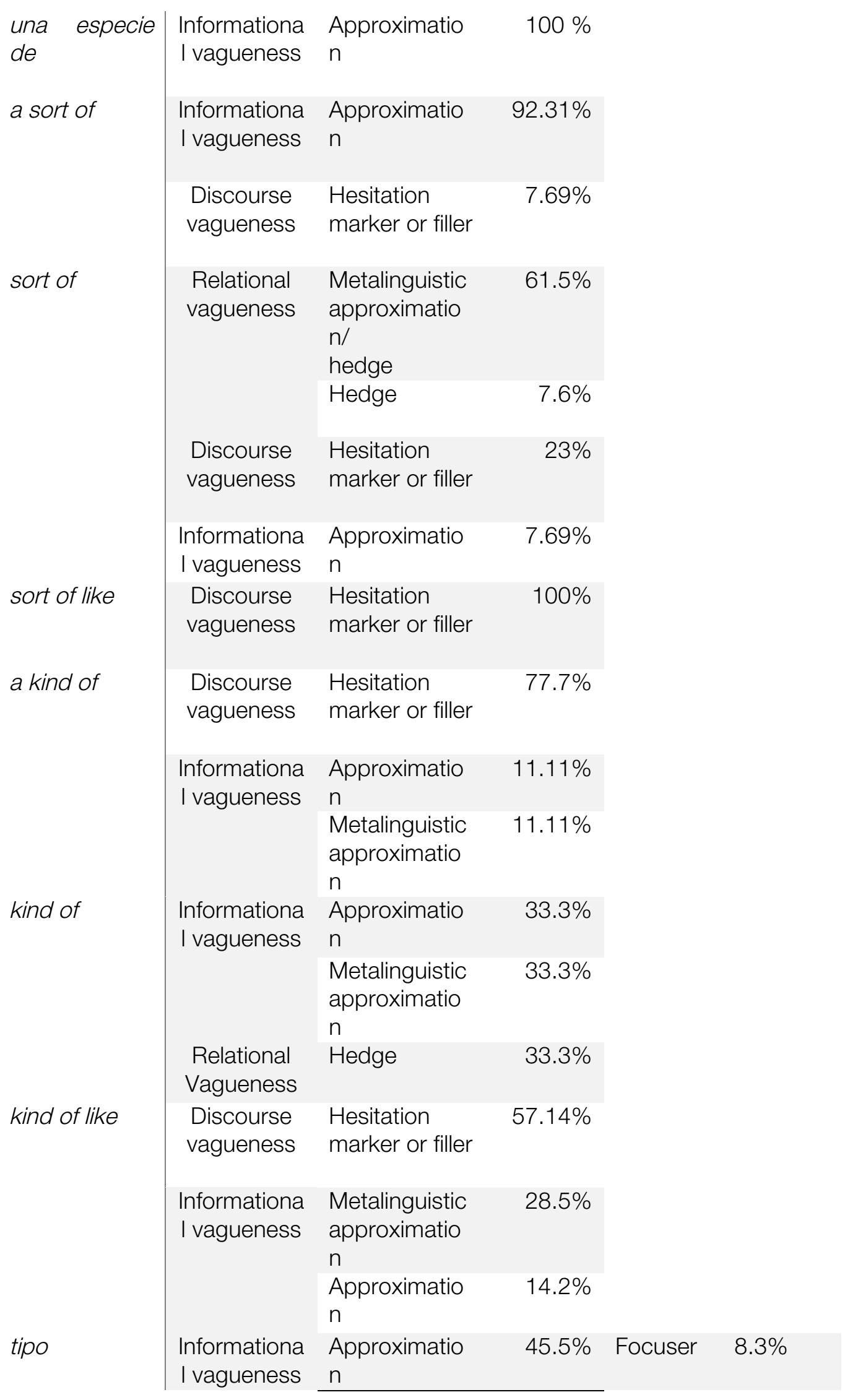




\begin{tabular}{|c|c|c|c|c|c|}
\hline & \multirow{2}{*}{\multicolumn{2}{|c|}{$54.55 \%$}} & & \\
\hline \multirow[b]{2}{*}{ como } & \multirow[b]{2}{*}{$\begin{array}{l}\text { Informationa } \\
\text { I vagueness }\end{array}$} & & & & \\
\hline & & $\begin{array}{l}\text { Approximatio } \\
\mathrm{n}\end{array}$ & $69.8 \%$ & & \\
\hline \multirow{5}{*}{ like } & $\begin{array}{l}\text { Discourse } \\
\text { vagueness }\end{array}$ & $\begin{array}{l}\text { Hesitation } \\
\text { marker or filler }\end{array}$ & $15 \%$ & & \\
\hline & $\begin{array}{l}\text { Relational } \\
\text { Vagueness }\end{array}$ & Hedge & $9.4 \%$ & & \\
\hline & $\begin{array}{l}\text { Informationa } \\
\text { I vagueness }\end{array}$ & $\begin{array}{l}\text { Metalinguistic } \\
\text { approximatio } \\
\mathrm{n}\end{array}$ & $5.6 \%$ & & \\
\hline & $\begin{array}{l}\text { Informationa } \\
\text { I vagueness }\end{array}$ & $\begin{array}{l}\text { Approximatio } \\
\mathrm{n}\end{array}$ & $22 \%$ & Focuser & $72 \%$ \\
\hline & $\begin{array}{l}\text { Discourse } \\
\text { vagueness }\end{array}$ & $\begin{array}{l}\text { Hesitation } \\
\text { marker or filler }\end{array}$ & $6 \%$ & & \\
\hline \multirow[t]{5}{*}{ diciamo } & $\begin{array}{l}\text { Discourse } \\
\text { vagueness }\end{array}$ & $\begin{array}{l}\text { Hesitation } \\
\text { marker or filler }\end{array}$ & $61.5 \%$ & & \\
\hline & $\begin{array}{l}\text { Informationa } \\
\text { I vagueness }\end{array}$ & $\begin{array}{l}\text { Metalinguistic } \\
\text { approximatio } \\
\mathrm{n}\end{array}$ & $20 \%$ & & \\
\hline & & $\begin{array}{l}\text { Approximatio } \\
\mathrm{n}\end{array}$ & $3 \%$ & & \\
\hline & $\begin{array}{l}\text { Relational } \\
\text { Vagueness }\end{array}$ & $\begin{array}{l}\text { Metacommun } \\
\text { icative marker }\end{array}$ & $7.6 \%$ & & \\
\hline & & $\begin{array}{l}\text { Indicator of } \\
\text { the point of } \\
\text { view of the } \\
\text { speaker }\end{array}$ & $7.6 \%$ & & \\
\hline \multirow[t]{3}{*}{ digamos } & $\begin{array}{l}\text { Discourse } \\
\text { vagueness }\end{array}$ & $\begin{array}{l}\text { Hesitation } \\
\text { marker or filler }\end{array}$ & $76.1 \%$ & & \\
\hline & $\begin{array}{l}\text { Informationa } \\
\text { I vagueness }\end{array}$ & $\begin{array}{l}\text { Metalinguistic } \\
\text { approximatio } \\
\mathrm{n}\end{array}$ & $19 \%$ & & \\
\hline & $\begin{array}{l}\text { Relational } \\
\text { Vagueness }\end{array}$ & Hedge & $4.7 \%$ & & \\
\hline
\end{tabular}

Table 4: vagueness and functions expressed by each VE. 


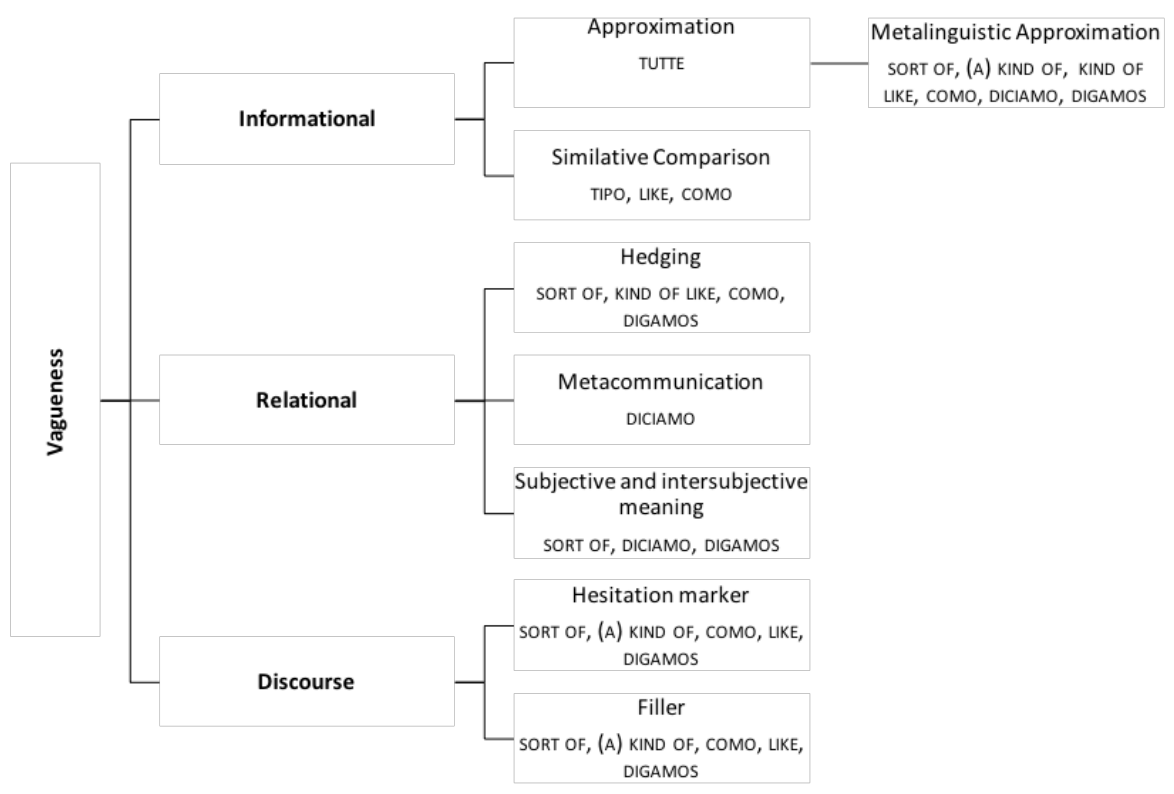

Figure 3: ramification of vaguenesses and functions

The first observation to do is the all the VEs can express informational vagueness through approximation. This means that is appear as the prototypical manifestation of linguistic vagueness. Moreover, all VEs, but una specie di and una especie de, cover a large space of semantic, pragmatic and discursive functions and these different functions are usually connected to different constructions or positions of the VEs in the utterance.

In the cases of a sort of vs. sort of the cancellation of the determiner is a further step towards the grammaticalization of the construction and its semantic bleaching. This favours the passage from a content meaning to a relational meaning and therefore from the expression of informational vagueness to relational one. In other cases, it is the position that allows one to determine whether the VE refers to a single constituent or to the entire utterance and therefore whether the low degree of specification affects the content or the point of view of the speaker. As we saw, the final position is usually reserved for relational vagueness and hedging, while discourse vagueness can be conveyed by different elements, which tend to co-occur in clusters and chains (Voghera 2014 and Voghera\&Collu in press). Some ambiguity can occur when the element which is in the scope of the VE is a predicate and therefore it cannot be always clear whether the low degree of specification affects its content or its illocutionary force. The position does not seem to have a distinctive role, as far as diciamo and digamos are concerned. In our data both VEs express mostly discourse vagueness, but also when they convey informational or relational vagueness can occupy different positions. This depends on the fact that as discourse markers they have a high degree of free movement in the utterance and this suggests that the position is not only determined by the function, but depends also on the status of the VE. 
Interestingly, like and tipo can be used as non-contrastive focusers. As already noted by Miller\&Weinert 1995, a non-contrastive focus is a textual mechanism, aiming at signaling that an element is salient and prominent in the discourse. The development of this function is a further step probably derived from the fact that, as similative markers, they introduce exemplar elements, which are salient. It is common, in fact, that like and tipo are used to introduce list constructions, aiming at clarifying or give more information.

The possibility of a VE to develop a focusing function is not so rare (Voghera 2017b), because focusing is a textual operation, which does not interfere with the degree of discriminability of a sign. In other words, we can focus signs that show different degree of discriminability and therefore also vague items.

In all three languages VEs can express multiple meanings, but if we have a VE with a unique function this is to convey informational vagueness: in other words, we do not have VEs that can express only relational or discourse vagueness. This probably depends on the fact that relational and discourse vagueness developed from information vagueness. This, on the one hand, suggests that there is a sort of hierarchy among the three types of vagueness, where the primary goal is to express the lack of information. On the other hand, it confirms a very well-known path, according to which many linguistic items and constructions develop a relational and pragmatic meaning from a more referential one (Traugott 1995; Hopper\&Traugott 2003).

As stated above, the aim of this paper was to describe the functional similarities and dissimilarities of some VEs in Italian, Spanish and English. Generally speaking, the similarities overwhelmed the differences, not only because the dialogues were collected in the same contexts, but because the items and the constructions which express vagueness manifest a very similar behaviour. This strongly supports the idea that the expression of vagueness follows some general semantic, pragmatic and discourse paths, which found their reason in cognitive and linguistic mechanisms widely shared interlinguistically.

\section{REFERENCES}

Bazzanella, Carla (1995): «I segnali discorsivi», in Renzi, Lorenzo et alii, eds., Grande grammatica di consultazione, Bologna, II Mulino, 225-257.

Bazzanella, Carla (2011): «Indeterminacy in dialogue», Language and Dialogue 1 (1) 21-23.

BRIZ, Antonio, PONS, Salvador, PORTOLÉS, José (2008): Diccionario de partículas discursivas del español. In: El diccionario como puente entre las lenguas y culturas del mundo. Actas del II Congreso Internacional de Lexicografía Hispánica. Alicante, Biblioteca Virtual Cervantes. p. 217-227.

Caffi, Claudia (2007): Mitigation, Amsterdam, Elsevier.

Channell, Joanna (1994): Vague language, Oxford, Oxford University Press.

Cutting, Joan. Vague language explored. Springer, 2007.

Denison, David, (2002): «History of the sort of construction family», Paper presented at the
Second International conference on Construction Grammar, Helsinki. September 6-28, 2002.

De Smedt, Liesbeth et alii (2007): «NP-internal functions and extended uses of the 'type' nouns kind, sort, and type: towards a comprehensive, corpus-based description», in Fachinetti, Roberta, ed., Corpus linguistics 25 years on, Amsterdam, Rodopi, 225-255.

Ghezzi, Chiara (2013): Vagueness Markers in Contemporary Italian: Intergenerational Variation and Pragmatic Change. Tesi di Dottorato, Università di Pavia.

Goldberg, Adele E. (1995): Constructions: A construction grammar approach to argument structure. University of Chicago Press.

Haspelmath, Martin y Oda Buchholz (1998): «Equative and simulative constructions in the language of Europe», in van der Auwera, Johan y Donall P. O Baoill, eds., Adverbial 
constructions in the languages of Europe, Berlin/New York, Mouton de Gruyter, 277-334.

Hölker, Klaus (2005): «Diciamo come mitigatore» in Hölker, K., \& Maass, C. (eds.). Aspetti dell'italiano parlato. LIT Verlag Münster, 2005. 53-79.

Hopper, Paul J., Traugott, Elizabeth Closs (2003): Grammaticalization. Cambridge University Press.

Jucker, Andreas H. and Sarah W. Smith (1998): "And people just you know like 'wow.' Discourse markers as Negotiating Strategies", in Jucker, Andreas H. y Yael Ziv, eds., Discourse Markers. Description and Theory (Pragmatics \& Beyond New Series 57), Amsterdam/Philadelphia, John Benjamins, 171-201.

Jucker, Andreas H. et alii (2003): «Interactive aspects of vagueness in conversation", Journal of Pragmatics 35, 1737-1769.

Kaltenböck, Gunther et alii (2010): New Approaches to Hedging, Bingley, Emerald.

Lindblom, Bjorn, (1990): «Explaining phonetic variation: a sketch of the H\&H theory", en Hardcastle William y Alain Marchal, eds., Speech production and speech modelling, Dordrecht, Kluwer, 403-439.

Meehan, Teresa (1991): «lt's Like, 'What's Happening in the Evolution of Like?': A Theory of Grammaticalization», in Ichihashi, Kumiko, y Mary Sarah Linn, eds., Kansas Working Papers in Linguistics, Volume 16, 37-51.

Mihatsch, Wiltrud (2007): "The construction of vagueness. "Sort of" expressions in Romance languages", in Radden, Gunter et alii, eds., Aspects of Meaning Constructing Meaning. From Concepts to Utterances, Amsterdam/Philadelphia, John Benjamins, 225-245.

Mihatsch, Wiltrud (2010): «The diachrony of rounders and adaptors: Approximation and unidirectional change" in Kaltenböck, Gunther et alii, eds., New Approaches to Hedging, Bingley, Emerald, 9 -93.

Mihatsch, Wiltrud (2016): «Type-noun binominals in four romance languages», Language Sciences, 53, 136-159.

Miller, Jim and Regina Weinert (1995): «The function of LIKE in dialogue», Journal of Pragmatics, 23, 365-393.

Müller, Simone (2005): Discourse Markers in Native and Non-native English Discourse, Amsterdam/Philadelphia, John Benjamins.

Overstreet, Maryann, (2011): «Vagueness and hedging", in Andersen, Gisle y Karin Aijmer, eds., Pragmatics of Society, Berlin/New York, Mouton de Gruyter, 293-317.

Savy, Renata (2010): «Pr. A. Ti. D: A Coding Scheme for Pragmatic Annotation of Dialogues", in n ELRA/ELDA Proceedings of the 7th Conference on International Linguistic Resources and Evaluation, 2141-2148.

Traugott, Elizabeth., (2010): «(Inter)subjectivity and (inter)subjectification: A reassessment», in Davidse, Kristin et alii, eds., Subjectification, Intersubjectification and Grammaticalization, Berlin/New York, Mouton de Gruyter, 29-69.

Voghera, Miriam (2012): «Chitarre, violino, banjo e cose del genere» in Thornton, Anna M. and Miriam Voghera, eds., Per Tullio De Mauro. Studi offerti dalle allieve in occasione del suo 80 compleanno, Roma, Aracne, 341-364.

Voghera, Miriam (2013): «A case study on the relationship between grammatical change and synchronic variation: the emergence of tipo[-N] in Italian", in Giacalone Ramat, Anna et alii, eds., Synchrony and Diachrony. A dynamic interface, Amsterdam/Philadelphia, John Benjamins, 283-312.

Voghera, Miriam (2014): Da nome tassonomico a segnale discorsivo: una mappa delle costruzioni di tipo in italiano contemporaneo, Studi di grammatica italiana. XXIII (2014), pp. 197-221.

Voghera, Miriam (2017a): La nascita delle costruzioni non nominali di specie, genere, sorta e tipo: uno studio basato su corpora. In: D’Achille, P., Grossmann, M. (eds.), Per la storia della formazione delle parole in italiano: un nuovo corpus in rete (M.I.DIA.) e nuove prospettive di studio. Firenze: Cesati.

Voghera, Miriam (2017b): «Quando vaghezza e focus entrano in contatto: il caso di un attimo, anzi un attimino" in D'Alessandro, Roberta et al. eds., Di tutti i colori. Studi linguistici per Maria Grossmann. Leiden University Repository (https://openaccess.leidenuniv.nl/).

Voghera, Miriam, Collu, Laura (in press): Intentional vagueness: a corpus-based analysis of Italian and German, Napoli, M., Ravetto, M., a cura di Intensity, intensification and intensifying modification across languages, Amsterdam/New York, Benjamins.

Waltereit, Richard (2006): «The rise of discourse markers in Italian: a specific type of language change», en Fischer, Kerstin, ed., Approaches to English Particles, Amsterdam, Elsevier, 6176. 